Volume 8, Issue 1, 157 - 168.

ISSN: 2165-8714

http://www.eu-jer.com/

\title{
Using Personal and Social Responsibility Model for Gaining Leadership Behavior in Students
}

\author{
Bijen Filiz * \\ Afyon Kocatepe University, TURKEY
}

Received: October 18, 2018 - Revised: December 8, $2018 \cdot$ Accepted: December 10, 2018

\begin{abstract}
In the research, it was aimed to teach responsibility to the students, ensure and develop awareness of leadership behavior using a leadership program, and also examine the effectiveness of the Teaching Personal and Social Responsibility (TPSR) model in terms of forming a leadership behavior. The study group consisted of 55 students in high school 1st grade attending Ankara Turkish Volleyball Federation Sports High School. In the study, mixed methods pattern with embedded semi-experimental pretest-posttest control group was used. While a 32-hour leadership program was being applied to the students in the experimental group, the current curriculum was continued to be taught for the students in the control group. As data collection tools, the Personal and Social Responsibility Behavior Scale, the Leader Behavior Description Questionnaire, a semi-structured individual interview form, and field notes were used. For findings; descriptive statistics and One-way Analysis of covariance (ANCOVA) were used in the analysis of quantitative data, and content analysis method was used in the analysis of qualitative data. As a result, the leadership program including 16 lectures delivered during eight weeks was effective in terms of teaching responsibility to the students of Sports High School and forming and developing leadership behaviors.
\end{abstract}

Keywords: Leadership, personal responsibility, physical education and sport, social responsibility, taking responsibility.

To cite this article: Filiz, B. (2019). Using personal and social responsibility model for gaining leadership behavior in students. European Journal of Educational Research, 8(1), 157-168. doi: 10.12973/eu-jer.8.1.157

\section{Introduction}

Adolescents and young people may exhibit various risky behaviors during adolescence such as relationship instability, emotional disability, alcohol-drug abuse, physical violence, suicidal tendency, and early sexuality (Kann et al., 1998). These behaviors significantly influence and shape young people's future experiences. Young people may remain limited in terms of finding solutions for their social and psychological problems. Positive Youth Development (PYD) programs can help to improve some of these issues.

There are many registered young people in public schools, who encounter a variety of challenges such as poverty, violence, drug use, depression, crime and alcohol abuse due to adverse social conditions and whose lives are at risk. Due to the exposure of young people to this "social toxic environment" (Garbarino, 1997) every day, likelihood of being more prone to leave school, develop risky behaviors and engage in criminal activities gradually increases. For these reasons, it is thought that the need to direct young people towards PYD has been increased (Sandford, Armour, \& Warmington, 2006). Studies in this field have proven that many PYD programs are effective in reducing risky behaviors and supporting positive outcomes (Catalano, Berglund, Ryan, Lonczak, \& Hawkins, 2004).

These programs, the numbers of which are increasing rapidly are carried out heavily in the field of physical activity and sports (Collingwood, 1997; Danish, Forneris, \& Wallace, 2005; Petitpas, Cornelius, Van Raalte, \& Jones, 2005; Sandford, Armour, \& Warmington, 2006). Examples of PYD programs include adventure education programs for after-school time and summer camps, coaching club programs for branches of sports, alternative physical education programs in school, leadership training, cross-age education, personal and social responsibility model, parent programs and instructiveness programs (Hellison et al., 2000). It has been seen that these programs can provide opportunities for interconnectedness in a group environment as well as development of life skills such as goal setting, respect for others, leadership, time management, responsibility, teamwork, and interpersonal skills that are believed to enable youth to successfully transition into adulthood (Danish, Forneris, \& Wallace, 2005; Gould \& Carson, 2008; Holt \& Neely, 2011; Whitley, Hayden, \& Gould, 2016).

\footnotetext{
* Correspondence:

Bijen Filiz, Afyon Kocatepe University, Coaching Education, Turkey.

\bijenfiliz@gmail.com
} 
One of these programs is Teaching Personal and Social Responsibility (TPSR) which is one of the physical activity curriculum models used in youth development and is extensively included in the education of the underprivileged youth community in the United States and around the world and in school physical education programs also including leadership training (Hellison, 2014). Young people should develop leadership skills to achieve success in their lives and to display positive youth behaviors. TPSR is effective in terms of making young people more responsible for social, moral and personal development and in terms of the development of leadership skills through the leadership education. It also helps young people to apply these concepts to other areas of their lives (Hellison, 2011, Martinek \& Hellison, 2009). TPSR has utilized sport, martial arts, and career exploration in a number of community program settings to deliver PYD programming (Hellison \& Walsh, 2002; Holt \& Jones, 2008; Martinek \& Hellison, 2009; Martinek, McLaughlin, \& Schilling, 1999; Melendez, 2011; Walsh, 2007; Wright \& Burton, 2008). These studies indicate that TPSR is a valid program framework for increasing such outcomes as it focuses on developing self-control, effort, selfcoaching, leadership and transference.

The starting point of leadership education is exclusion and injustice. The source of negative adolescent behaviors such as criminality and violence emerge in young people who are not adequately served as to the result of exclusion and injustice is linked to racism and poverty. It is important to impress the TPSR values for young people in the risk group to grow up in a more caring and compassionate society, the moral and social responsibility to form a healthy interaction with the young people's characters, and the citizenship spirit with the help of TPSR (Martinek \& Hellison, 2009). It is possible to implement them with the TPSR implementations and leadership training program.

When leadership training is given to young people, the levels of TPSR are utilized. TPSR practice is based on five levels of responsibility: (a) respect for the rights and feelings of others, (b) effort/participation, (c) self-direction, (d) helping others/leadership and (e) transferring out of the sports hall. Strategies used to help participants to practice these levels are relational time, awareness talk, physical activity plan, group meeting and self-reflection time (Hellison, 2014). In the leadership development of young people, the stages of learning to take responsibility, leadership awareness, cross-age leadership and self-realization leadership (transferring out of the sports hall) take place (Martinek \& Hellison, 2009, p. 43). While TPSR levels are being transferred to the young people in the implementation of TPSR leadership programs, the development stages are given step-by-step in these levels.

In the implementation of the TPSR leadership program, a question-and-answer environment on young people's experiences is provided in group meetings and reflection times in order to raise awareness about leadership behaviors. Moreover, young people are given the chance to lead together with peer groups during the activities (Hellison, 2011). Cross-age education offers opportunities for young people to help, eliminate, and provide feedback to younger ones or to other young people in the same age group. Cutforth and Puckett (1999) have reported that instruction of cross-age improves self-confidence, self-esteem, and problem-solving skills. Similarly, Cutforth (2000) reported that the instruction of cross-age helps participants become more independent and reflective. Finally, during the implementation of the program, the responsibilities in the planning and execution of the program are gradually shifted from program leaders to young people, in order to lead young people to take leadership and take responsibility (Hellison et al., 2000).

While providing leadership training with TPSR opportunities are given to improve responsibility and leadership skills such as having team spirit, having cross-age leadership, establishing trust, cooperating, supporting, peer coaching, apprentice teaching, encouraging critical thinking, giving an opportunity to think about how to behave, giving responsibility, encouraging for positive moral judgment, taking the responsibility from children who demonstrate recession, establishing a balance of power, and using the principle of accordion for balancing. (Martinek \& Hellison, 2009, p. 43).

Having youth leaders included in PYD programming involves intentionally placing youth in leadership roles such as facilitating program activities (Hellison, 1995). When the overall objective of the PYD programs is considered, it is important for the participation of the young people to develop their leadership characteristics. Furthermore, it is necessary to conduct research on how to develop leadership characteristics of young people and to understand the impact of PYD programs on improving leadership characteristics. In this context, the TPSR leadership program, which is one of the PYD programs, is expected to increase the awareness and the develop responsibility and leadership in young people. Moreover, the results of this study can highlight how to help young people to contribute to leadership development and can emphasize ways to improve PYD programs.

\section{Purpose}

In this study, the effectiveness of the model on gaining leadership behavior was examined on athlete students. All students in TVF Sports High School constituting the study group take place as an athlete in various sports clubs. Athlete students are expected to be disciplined, technic, responsible, patient and participative, and to have a goal, sense of mission and sports culture. From this point of view, it is important that the athlete students, who study in TVF Sports High School, show the responsibility behaviors stated in the TPSR in and outside the gym, establish a positive athlete identity and show athletic success.

Furthermore, athlete students prefer to study in this school in order to have professions such as a physical education teacher, sports manager or coach. In this context, it is important for the students to be able to feature and show their 
leadership qualities in their future professions in addition to their sports life. Applying programs that can bring out leadership qualities to students will contribute to the development of leadership behaviors and awareness about leadership behaviors. TPSR has been preferred for the leadership program, as it includes the level of leadership/cooperative behavior in the implementation of the model. In the TPSR, the leadership behavior is given to students step by step from the first level. Therefore, in the current study it has been aimed to teach responsibility to the students, to provide and develop awareness of leadership behaviors and to examine the effectiveness of the model in terms of forming a leadership behavior using TPSR leadership program from PYD programs.

Moreover, the TPSR program in Turkey is not actively used in physical education and sports lessons and sports training in Turkey. The positive results obtained from such research studies show that the TPSR also works in Turkey. Therefore, the use of TPSR in physical education and sports lessons and in sports training will be effective in providing behaviors for students such as taking responsibility, helping and leading, and it will provide diversity in the field as a method. The results of this study set an example to physical education teachers in Turkey and the world, coaches, researchers and academics in terms of achievements of the TPSR. The sub-problems of the study were determined as follows:

1. Is there any significant difference between the pretest-posttest scores of the experimental group where the training was performed with the TPSR leadership program and the control group without TPSR regarding leadership behaviors?

2. What are the opinions of athlete students in the experimental group where the training was performed with the TPSR leadership program about leadership behaviors?

\section{Method}

\section{Research Design}

In this study, embedded semi-experimental mixed methods design was used. Creswell and Clark (2007) have described the embedded design, one of the mixed method designs as "One of the qualitative or quantitative methods is more prominent than the other; research is a qualitative or quantitative research, but it is defined that the data obtained by the alternative method for supporting, generalizing or explaining the data are needed." Embedded designs can be performed in one stage or two stages, quantitative and qualitative data are used to answer different research questions. The control group pretest-posttest semi-experimental design was supported by the qualitative data collection tools in order to obtain in-depth knowledge during the experimental process, and by this way, answers was sought for the research questions. During the experimental process, the TPSR leadership program was applied to the students in the experimental group by the researcher and in the control group, the current curriculum continued to be taught by the course teacher. Research design of the study is shown in Table 1.

Table 1. Research Design of the Study

\begin{tabular}{llll}
\hline Group & Pretest & Process & Posttest \\
\hline \multirow{4}{*}{ Experiment } & & $\begin{array}{l}\text { 1. Personal and Social Responsibility Behavior } \\
\text { Scale }\end{array}$ \\
& $\begin{array}{l}\text { 1. Personal and Social } \\
\text { Responsibility Behavior Scale } \\
\text { 2. The Leader Behavior Description } \\
\text { Questionnaire }\end{array}$ & $\begin{array}{l}\text { TPSR } \\
\text { leadership } \\
\text { program }\end{array}$ & $\begin{array}{l}\text { 2. The Leader Behavior Description } \\
\text { Questionnaire }\end{array}$ \\
& & $\begin{array}{l}\text { 3. Semi-Structured individual student } \\
\text { interviews }\end{array}$ \\
\hline \multirow{3}{*}{ Control } & 1. Personal and Social & 1. Personal and Social Responsibility Behavior \\
& Responsibility Behavior Scale & Traditional & Scale \\
& 2. The Leader Behavior Description & practice & 2. The Leader Behavior Description \\
& Questionnaire & & Questionnaire \\
\hline
\end{tabular}

\section{Study Group}

In the current study, a total of 55 athlete students in the high school $1^{\text {st }}$ grade of Ankara TVF Sports High School were included during the fall semester of 2015-2016, and it was on a voluntary basis using convenience sampling, which is one of the purposeful sampling methods requiring selection of individuals or situations that can give information related to the research subject (Yildirim \& Simsek, 2006). The reason for choosing the convenience sampling method; was that the researcher worked as a physical education teacher in the school chosen for the research and that all of the implementations included in the research were done by him/herself. In this method, the researcher selected a situation close and easy to access (Yildirim \& Simsek, 2006). In the study, the class 10-A which chosen by random assignment method formed the experimental group and 10-B formed the control group.

There were 28 athlete students (17 females, 11 males) in the experimental group and 27 athlete students (11 females, 16 males) in the control group. According to this study, $50.7 \%$ of the 55 students constituting the study group were 
females, and $49.3 \%$ were males. The age of the students ranged from 15 to 16 , the average age of the students in the experimental group was $15.2 \pm 1.3$, while the average age of the control group was $15.2 \pm 1.2$.

\section{Data Collection Tools}

Personal and Social Responsibility Behavior Scale (PSRB-S). PSRB-S developed by Filiz and Demirhan (2018) consists of 14 items. Seven items represent personal responsibility and the other seven items represent sub-dimensions of social responsibility. The scale is a 4-point Likert type and the highest score is 56 and the lowest score is 14 . There is no item that is negatively scored in the scale.

The sub-dimension for social responsibility of the test scale is represented by two of TPSR levels: Respect for the rights and feelings of others and helping others/leadership. Exemplary items are as follows: "I control my behaviors towards others", "I do independent study related to my skill level without directed by someone else". The sub-dimension of personal responsibility is represented by the other two of TPSR levels: Effort/participation and self-direction. Exemplary items are as follows: "I prepare my work plan according to my personal needs" and "I give effort to overcome difficult tasks". The items are distributed as four items for the level of respecting others' rights and feelings, three items for the level of effort/participation, four items for the level of self-direction, and three items for the level of helping others/leadership.

The scale was applied to 330 high school students for exploratory factor analysis. For the reliability of the scale; the Cronbach Alpha coefficient regarding two factors was .82, the Cronbach Alpha coefficient for the first sub-factor was .78, and the Cronbach Alpha coefficient for the second sub-factor was .70. For confirmatory factor analysis, the scale was applied to 250 different high school students. As a result of the analysis, values were obtained as $\chi 2 / \mathrm{sd}=1.05$, $\mathrm{RMSEA}=.014, \mathrm{SRMR}=.050, \mathrm{CFI}=.99, \mathrm{NFI}=.93, \mathrm{NNFI}=.99$, and $\mathrm{GFI}=.96$.

The Leader Behavior Description Questionnaire (LBDQ). LBDQ has been developed by Halpin and Winer (1957). In the present study, scale expressions applied to university students by Atar and Ozbek (2009) have been applied. There are 30 items on the scale regarding leadership behavior, 15 of which are related to initiation of structure and 15 of them to the aspect of consideration. The LBDQ are 5-item Likert type. Items 3 and 7 in the sub-dimension for initiation of structure and items $20,22,23$ and 24 in the sub-dimension for consideration were negatively scored. In the scale of 30 items in total, the maximum score is 150 and minimum score is 30 , whereas the maximum score is 75 and minimum score is 15 in the sub-dimensions.

Halpin and Winer (1957) state the two sub-dimensions of LBDQ as follows: The initiation of structure includes the relationships between the leader and the group members, the efforts to establish a well-defined organizational structure, the communication rules and the ways to have work done. On the other hand, understanding includes behaviors related to friendship in the group, warmness between the leader and the group members, mutual trust and respect. Exemplary items are as follows: "I clearly state what I expect from them about their missions" and "I try to apply the suggestions given by my friends".

The orginal scale that the Alpha internal consistency coefficient calculated on physical education and sports college students for the reliability was found to be .78 for initiation of structuring dimension and .78 for considerating dimension (Atar \& Ozbek, 2009). In this study, the scale was applied to 181 high school students for validity and reliability. As a result of confirmatory factor analysis made for validity, results were found as $X^{2}=860.03$, $s d=401$, $\mathrm{X}^{2} / \mathrm{sd}=2.14, \mathrm{RMSA}=.080, \mathrm{NFI}=.75, \mathrm{NNFI}=.84, \mathrm{GFI}=.76$, and $\mathrm{SRMR}=.091$. Alpha internal consistency coefficient made for the reliability of the scale was calculated as .80, the dimension of initiation of structure as .66 and the dimension of consideration as .66.

Semi-Structured Individual Student Interviews. After the implementation of the TPSR leadership program, semistructured individual student interviews were conducted with 10 students selected from the experimental group according to the random sampling method. Interview questions were prepared by the researcher in the direction of the research purposes and in the light of the TPSR literature (Hellison, 2011; Hellison \& Cuthforh, 2000). Each of the interviews took about 30 minutes. The interviews were conducted by the researcher in the sports room belonging to the Physical Education Teachers of the TVF Sports High School and all interviews were recorded with a video camera by taking permission from the students. All the negotiations made were converted to words by the researcher.

Field notes. The responses obtained from the discussions made during class meetings and reflection times of the course implementations have been noted by the researcher and some of these answers have been included in the resultdiscussion part.

\section{Data Collection Process and Intervention}

The study was conducted with 55 students in the high school $1^{\text {st }}$ grade of Ankara TVF Sports High School two days a week, during eight weeks and 16 lessons. In preparing the lesson plans, sources and sample applications of Hellison (1978), Hellison (2011), Hellison and Cutforth (2000), and Martinek and Hellison (2009) were used. The lesson plans prepared in accordance with the TPSR were formed as a program based on cooperative activities covering leadership behaviors. 
The TPSR program was applied to the students for the first four weeks and one level which was among the indicated levels in the model was transferred to the students each week (respecting the rights and feelings of others, effort/participation, self-direction, helping others/leadership). A general course flow, in accordance with the TPSR model, consisted of five sections: Relational time, awareness talk, physical activity plan, group meeting and reflection time.

From the $15^{\text {th }}$ week students were assigned tasks, and students were given an opportunity to recognize and develop leadership behaviors through peer coaching and activities enabling them to lead. At the end of each lesson, group meetings were held and students were asked to share opinions about the leadership behaviors they had experienced and they were provided with awareness about leadership behaviors. Experimental manipulations in the study are shown in Table 2.

Table 2. Experimental Manipulations in the Study

\begin{tabular}{|c|c|c|c|c|}
\hline Week & Level & Goal & Sub-goal & Activities \\
\hline 1 & $\begin{array}{l}\text { 1- Respecting the } \\
\text { rights and } \\
\text { feelings of others }\end{array}$ & $\begin{array}{l}\text { Self-control, } \\
\text { inclusion to the } \\
\text { game }\end{array}$ & $\begin{array}{l}\text { Respecting the right to participate, } \\
\text { providing confidence to each other, } \\
\text { communication }\end{array}$ & $\begin{array}{l}\text { Acquaintance games } \\
\text { Fusion games }\end{array}$ \\
\hline 2 & $\begin{array}{l}\text { 1- Respecting the } \\
\text { rights and } \\
\text { feelings of others }\end{array}$ & $\begin{array}{l}\text { Self-control, } \\
\text { inclusion to the } \\
\text { game }\end{array}$ & $\begin{array}{l}\text { Finding logical solutions to problems, } \\
\text { providing confidence to each other, } \\
\text { communication }\end{array}$ & $\begin{array}{l}\text { Acquaintance games } \\
\text { Fusion games }\end{array}$ \\
\hline 3 & $\begin{array}{l}\text { 2- Effort/ } \\
\text { participant }\end{array}$ & $\begin{array}{l}\text { Discovering the } \\
\text { effort }\end{array}$ & $\begin{array}{l}\text { Taking responsibility, motivation, } \\
\text { self-responsibility }\end{array}$ & Fitness test \\
\hline 4 & $\begin{array}{l}\text { 2- Effort/ } \\
\text { participant }\end{array}$ & Trying new tasks & $\begin{array}{l}\text { Effort, collaboration, strategy } \\
\text { development, motivation }\end{array}$ & $\begin{array}{l}\text { Games with pilates ball } \\
\text { Frizby }\end{array}$ \\
\hline 5 & 3- Self-direction & Independent study & $\begin{array}{l}\text { Goal setting, self-development, focus, } \\
\text { motivation }\end{array}$ & $\begin{array}{l}\text { Sports games } \\
\text { Yoga }\end{array}$ \\
\hline 6 & 3- Self-direction & Independent study & Goal setting, self-development, focus & Station work \\
\hline 7 & $\begin{array}{l}\text { 4- Helping } \\
\text { others/leadership }\end{array}$ & Create a team & $\begin{array}{l}\text { Building trust, focusing on achieving } \\
\text { the same goal, trusting the leader }\end{array}$ & $\begin{array}{l}\text { Team and trust building } \\
\text { games }\end{array}$ \\
\hline 8 & $\begin{array}{l}\text { 4- Helping } \\
\text { others/leadership }\end{array}$ & Team work & $\begin{array}{l}\text { Creative thinking, cooperation, self- } \\
\text { expression, motivation, self- } \\
\text { responsibility }\end{array}$ & Volleyball \\
\hline 9 & $\begin{array}{l}\text { 4- Helping } \\
\text { others/leadership }\end{array}$ & $\begin{array}{l}\text { Team game } \\
\text { Creating the team } \\
\text { spirit }\end{array}$ & $\begin{array}{l}\text { Strategy development, leadership, } \\
\text { communication }\end{array}$ & Football \\
\hline 10 & $\begin{array}{l}\text { 4- Helping } \\
\text { others/leadership }\end{array}$ & Peer coaching & $\begin{array}{l}\text { Helping, self-confidence, self-esteem, } \\
\text { motivation, focus, self-responsibility, } \\
\text { leadership }\end{array}$ & $\begin{array}{l}\text { Preparing the gymnastics } \\
\text { show }\end{array}$ \\
\hline 11 & $\begin{array}{l}\text { 4- Helping } \\
\text { others/leadership }\end{array}$ & Peer coaching & $\begin{array}{l}\text { Problem solving, effort, } \\
\text { communication, leadership }\end{array}$ & Tae-kwon-do \\
\hline 12 & $\begin{array}{l}\text { 4- Helping } \\
\text { others/leadership }\end{array}$ & Team game & $\begin{array}{l}\text { Honesty, strategy development, self- } \\
\text { direction }\end{array}$ & Dodgeball \\
\hline 13 & $\begin{array}{l}\text { 4- Helping } \\
\text { others/leadership }\end{array}$ & Problem solving & $\begin{array}{l}\text { Respect, honesty, communication, } \\
\text { security, self-direction }\end{array}$ & Flag hiding game \\
\hline 14 & $\begin{array}{l}\text { 4- Helping } \\
\text { others/leadership }\end{array}$ & Compromise & Effort, honesty & Infection game \\
\hline 15 & $\begin{array}{l}\text { 4- Helping } \\
\text { others/leadership }\end{array}$ & Team game & $\begin{array}{l}\text { Honesty, decision making, self- } \\
\text { direction, basketball skills acquisition } \\
\text { (mental and physical) }\end{array}$ & Basketball \\
\hline 16 & $\begin{array}{l}\text { 4- Helping } \\
\text { others/leadership }\end{array}$ & $\begin{array}{l}\text { Cross-age } \\
\text { education }\end{array}$ & Helping, trust, leadership & $\begin{array}{l}\text { Preparing the dance } \\
\text { show }\end{array}$ \\
\hline
\end{tabular}

After the students in the experimental and control groups were informed about the study, PSRB-S developed by the researcher and LBDQ developed by Halpin and Winer (1957) were applied with the purpose of collecting quantitative data for the pretest. Subsequently, the TPSR leadership program was applied to the students in the experimental group for eight weeks. The current curriculum continued to be taught to the students in the control group. The control group's sports lessons were conducted by the Physical Education Teacher from another school. After the implementation, the same scales were re-applied to the students in the experimental and control groups as a posttest. Furthermore, semistructured individual interviews were conducted with 10 students selected by random sampling method from the experimental group. 
Before the research, approvals were received from the Hacettepe University Ethical Committee (03.11.2015/3102) and from all participants, and instructions projected by the Hacettepe University Ethical Committee were followed throughout the research. The participants were informed about the content of the research and their rights, and they were requested to sign an approval form. The participants were assured that participating in the research would not affect their course grades by any means and the research was grounded on voluntariness. Nicknames were used throughout the study in order to provide confidentiality. Then necessary official permissions were obtained from the Ankara Governorship and the Provincial Directorate for National Education.

\section{Data Analysis}

In the analysis of quantitative data, descriptive statistics for basic definitions of scales, and One-way Analysis of covariance (ANCOVA) for pretest and posttest scores obtained from PSRB-S and LBDQ were used. According to Tabachnick and Fidell (2013), it is appropriate to use covariance technique in cases where real random assignment cannot be made and the real random selection could not be performed for the experiment and control group. PSBR-S and LBDQ's pretest scores were checked, and ANCOVA was used to compare posttest scores. SPSS 20.0 package program was used in the analysis of quantitative data.

Content analysis method was used in the analysis of qualitative data. Within the scope of this analysis technique, the data obtained from the semi-structured interviews were examined independently by two experts (researcher and a faculty member in the field of sports sciences) and codes were found, and their frequency analyses were conducted. The frequency of the opinions that were classified was determined, and the conclusions were interpreted via the obtained data (Silverman, 2006).

For the validity and reliability of this study, the variation method was used. In this method, the researcher can both observe and interview the participants or use both qualitative and quantitative methods. Data from one method can be compared to those obtained from the other method (Holloway \& Wheeler, 2010). More than one method (scales, field notes, semi-structured individual interviews) was used for methodological variation. For research variation multiple researchers were included in the study. For data variation, data were collected from different people at different times. Therefore, the validity and reliability of all data were obtained using three different methods.

\section{Results}

The pretest and posttest total scores of the students obtained from the PSRB-S and LBDQ were found to be in the range of -1.5 and +1.5 Skewness and Kurtosis, and the analysis continued as follows by considering that data were normally distributed (Tabachnick \& Fidell, 2013). The Skewness and Kurtosis values of the PSRB-S and LBDQ scales are shown in Table 3.

Table 3. The Skewness and Kurtosis Values of the PSRB-S and LBDQ Scales

\begin{tabular}{lllllll}
\hline & & $\boldsymbol{N}$ & Skewness & & Kurtosis \\
\hline \multirow{3}{*}{ PSRB-S } & & Statistic & Statistic & Std.Error & Statistic & Std.Error \\
\cline { 3 - 7 } & & 55 & -.258 & .322 & -.619 & .634 \\
\multirow{2}{*}{ PBDQ } & Pretest & 55 & -1.048 & .322 & 1.197 & .634 \\
& Posttest & 55 & .115 & .322 & -.489 & .634 \\
& Pretest & 55 & .060 & .322 & -.243 & .634 \\
\hline
\end{tabular}

Findings related to the Personal and Social Responsibility Behavior Scale (PSRB-S)

The mean and standard deviation values of the pretest and posttest scores of the students obtained from PSRB-S are given in Table 4.

Table 4. Mean $(\bar{X})$ and Standard Deviation (Sd) of Two Sub-Dimensional Structures of PSRB-S

\begin{tabular}{lllcccc}
\hline Dependent variable & Group & $\mathbf{N}$ & Pretest $\overline{\mathbf{X}}$ & Sd & Posttest $\overline{\mathbf{X}}$ & Sd \\
\hline Social responsibility & Experiment & 28 & 3.54 & .35 & 3.66 & .37 \\
& Control & 27 & 3.46 & .34 & 3.35 & .47 \\
Personal responsibility & Experiment & 28 & 3.27 & .46 & 3.61 & .33 \\
& Control & 27 & 3.32 & .42 & 3.20 & .46 \\
Total & Experiment & 28 & 3.40 & .36 & 3.64 & .31 \\
& Control & 27 & 3.39 & .33 & 3.28 & .41 \\
\hline
\end{tabular}

According to Table 4, when the posttest total scores of the students in the experimental and control groups were taken into consideration, it was seen that the scores of the experimental group that the TPSR leadership program was applied to were higher than the control group to which the program was not applied. Moreover, according to the posttest scores, it was seen that there was an increase in both personal responsibility and social responsibility scores of the 
students in the experimental group. In students of the control group, there was a decrease in both personal responsibility and social responsibility scores.

ANCOVA results, which was conducted to determine whether there was a significant difference between the posttest scores when the pretest scores were controlled, have been given in Table 5.

Table 5. ANCOVA Results for PSRB-S

\begin{tabular}{lllllll}
\hline Source & Sum of squares & Df & Mean square & $\boldsymbol{F}$ & $\boldsymbol{\eta}^{2}$ & $\boldsymbol{p}$ \\
\hline Covariate (pretest) & .849 & 1 & .849 & 7.072 & .120 & $.01^{*}$ \\
Group (experiment/control) & 1.696 & 1 & 1.696 & 14.132 & .214 & $.00^{*}$ \\
Error & 6.240 & 52 & .120 & & & \\
Total & 667.184 & 55 & & & & \\
\hline
\end{tabular}

$p<.05^{*}$

In Table 5, according to the pretest of the experimental and control groups, there was a statistically significant difference between corrected posttest point averages $[F(1,52)=14.132, p=.00, p<.05]$. According to the results of the Bonferroni test, there was a significant difference between the posttest mean score of the experimental group $(X=3.635)$ and the control group $(X=3.277)$ in favor of the experimental group. According to classification of Kinnear and Gray (1999), it has been observed that the effect size is in the high level $\left(\eta^{2}=.214\right)$.

Findings related to the Leader Behavior Description Questionnaire (LBDQ)

The mean and standard deviation values of the pretest and posttest scores of the students obtained from the LBDQ have been given in Table 6 .

Table 6. Mean $(\bar{X})$ and Standard Deviation (Sd) Values of Two Sub Dimensional Structure of LBDQ

\begin{tabular}{lllrrrr}
\hline Dependent variable & Group & N & Pretest $\overline{\mathbf{X}}$ & Sd & Posttest $\overline{\mathbf{X}}$ & Sd \\
\hline Initiation of structure & Experiment & 28 & 3.83 & .42 & 4.18 & .36 \\
& Control & 27 & 3.81 & .39 & 3.78 & .32 \\
Consideration & Experiment & 28 & 3.85 & .44 & 4.10 & .34 \\
& Control & 27 & 3.93 & .42 & 3.92 & .38 \\
Total & Experiment & 28 & 3.84 & .40 & 4.14 & .31 \\
& Control & 27 & 3.87 & .36 & 3.85 & .30 \\
\hline
\end{tabular}

According to Table 6, when the posttest total scores of the students in the experimental and control groups have been taken into account, it has been found that there is an increase in the scores of initiation of structure and consideration dimensions of the students in the experimental group that the TPSR leadership program has been applied to according to the posttest scores, and it is also seen that the scores of initiation of structure have been increased higher than the scores of consideration. In terms of the students in the control group, it has been observed that there is a decrease in the total scores of initiation of structure and consideration.

The results of the ANCOVA which was conducted to determine whether there was a significant difference between the posttest scores when the pretest scores were controlled have been given in Table 7.

Table 7. ANCOVA Results for $L B D Q$

\begin{tabular}{lllllll}
\hline Source & Sum of squares & df & Mean square & $\boldsymbol{F}$ & $\boldsymbol{\eta}^{2}$ & $\boldsymbol{p}$ \\
\hline Covariate (pretest) & 1.839 & 1 & 1.839 & 30.191 & .367 & $.00^{*}$ \\
Group (experiment/control) & 1.316 & 1 & 1.316 & 21.606 & .294 & $.00^{*}$ \\
Error & 3.167 & 52 & .061 & & & \\
Total & 885.932 & 55 & & & & \\
\hline
\end{tabular}

$p<.05^{*}$

In Table 7, according to the pretest of the experimental and control groups there was a statistically significant difference between corrected posttest point averages $[F(1,52)=21.606, p=.00, p<.05]$. According to the results of the Bonferroni test, there was a significant difference between the posttest mean score of the experimental group $(X=4.144)$ and the control group $(X=3.849)$ in favor of the experimental group. According to classification of Kinnear and Gray (1999), it has been observed that the effect size is in the high level $\left(\eta^{2}=.294\right)$. The results obtained from the PSRB-S and LBDQ scales showed that there was a significant difference in favor of the experimental group in the posttest, and that the TPSR leadership program was effective in providing the responsibility and leadership to the students. 


\section{Findings on Semi-structured Individual Student Interviews}

At the end of 16 lessons, semi-structured individual interviews were held with 10 students. Ten questions were asked to the students, but three questions were evaluated for the purpose of the research. The frequency table obtained as a result of the content analysis regarding the students' opinions on leadership has been demonstrated in Table 8.

Table 8. Student Views on Leadership

\begin{tabular}{|c|c|c|}
\hline Evaluation Questions & Opinions & $f$ \\
\hline \multirow{5}{*}{$\begin{array}{l}\text { 1. How did you feel about the lessons conducted for the TPSR } \\
\text { leadership program? }\end{array}$} & Self-confidence & 8 \\
\hline & Awareness & 6 \\
\hline & Shyness & 3 \\
\hline & Taking Responsibility & 3 \\
\hline & Communication & 3 \\
\hline \multirow{6}{*}{$\begin{array}{l}\text { 2. What did you feel when you played sports in the TPSR } \\
\text { leadership program? }\end{array}$} & Taking Responsibility & 5 \\
\hline & Making an Effort & 3 \\
\hline & Exchanging Ideas & 2 \\
\hline & Planning & 4 \\
\hline & Finding Solutions & 2 \\
\hline & Setting a Target & 3 \\
\hline \multirow{4}{*}{$\begin{array}{l}\text { 3. Would you name a behavior that has been improved in your case } \\
\text { as a result of the TPSR leadership program? }\end{array}$} & Taking Responsibility & 5 \\
\hline & Cooperation & 3 \\
\hline & Leading & 4 \\
\hline & Respecting & 4 \\
\hline
\end{tabular}

In Table 8 regarding the first question, the students have stated that they are aware of self-confidence and awareness in terms of being leaders in the lessons they practice. While the number of students feeling self-confidence is eight, the number of awareness is six. Three students have stated that they have the feelings of shyness, communication and responsibility. Some students' opinions on this issue are as follows:

"Our confidence has been increased in every aspect. Even though you are the leader you always share your opinion and I do not decide on everything, I also talk friendly with many people and sharing my opinion has increased my self-confidence" (Gizem). "I felt more confident and took more responsibilities, and they listened to me" (Cigdem). "I did not even know names of all the friends, we have integrated as a class, I did not know how to behave in terms of helping, I have learned that it is more important, it really needs responsibility" (Mert). Two students have stated that they have been able to overcome their shyness and they can lead the game thanks to these implementations: "I think I can be a leader, before I did not participate in such things a lot, I was afraid that they would not respect me or afraid to make mistakes, but now I am confident, I think I can become a leader" (Furkan). "At first I was afraid of being a leader but when I have started to take responsibility I started to love this work" (Oznur). One student has stated that this study has not made much contribution to him in terms of leadership skills: "I did not attend to the leadership activities, I do not think that I can be a leader, I can be a leader in the sports I make, but I could not do it in this activity, I am timid, I have to know the group before, I was a bit confident, and my team also had a little influence" (Firat).

Regarding the second question, the students stated that they have shown leadership behaviors such as taking responsibility, making an effort, exchanging ideas, making plans, solving problems, and setting goals while doing sports in the leadership program. The number of students indicating that they have taken responsibility is five, four students have indicated that they are making plans, three students have stated that they have made an effort and set a goal, and two students have indicated that they are exchanging ideas and finding solutions. The students have stated that they have shown taking responsibility at most. Some students' opinions on this issue are as follows:

"While I was leading I was listening to the opinions of the people who know better, and I thought that I should do it with the someone who knows it" (Furkan), "I felt so good, I felt more energetic, even if I did not like it I wanted to participate in everything and I played by thinking if I could do my best" (Dilan), "I feel better when I make friends to do things, I have to make myself and my friends to do it right, I feel better because my responsibility has increased " (Gizem), "You gave us tasks at the end of the lesson, and we attended the next lesson by planning, and we applied the plan that we had prepared for our friends" (Firat), "I learned that I need to set short and long-term goals for sports and lessons" (Mert).

As regards the third question, it was seen that at the end of the program, students gained the leadership behaviors that include levels of personal and social responsibility model. According to the TPSR, cooperation and leadership are expected to be gained at the fourth level. These results showed that the responsibility of the TPSR leadership program was effective in terms of learning responsibility and providing and developing awareness in leadership, and it was seen that the present study reached its goals. 


\section{Conclusion and Discussion}

In this study, it was aimed to enable students to gain and take responsibility and leadership by using the TPSR leadership program which is one of the PYD programs. At the same time, the effect of the program on gaining leadership was examined. As a result of the research, it was seen that the TPSR leadership program was effective in gaining and developing leadership of athletes. In mixed method, both qualitative and quantitative data were analyzed separately and combined in the discussion section.

In the PSRB-S and LBDQ scales, when the pretest scores and the posttest scores of the groups were compared, there was no significant change in the scores of the control group in spite of the significant increases in all dimensions and total scores of the experimental group supported, the significant differences among the groups in terms of the posttest scores. These results have showed that the TPSR leadership program has been effective in terms of learning responsibility and providing and developing awareness in leadership behavior. The statement that the posttest scores of the students in the experimental group are significantly higher than the scores of the students in the control group reflected in the study conducted by Escartí, Gutiérrez, Pascual, and Llopis (2010) showing that there is a significant increase in the self-control competencies as a result of the implementation of the TPSR-demonstrates similarities with the findings of the present study. Bulca's (2013) study of physical fitness within the context of TPSR as an extracurricular activity supports the findings of this research as the pretest and the posttest results show that TPSR has an effect on the development of self-efficacy and sense of responsibility. Grandzol (2011) has investigated the development of leadership qualities before and after the game season using 31 team captains in university sports teams using Kouzes and Postner's Student Leadership Practices Inventory. During the season, the behaviors of the captains were observed, and at the end, the same inventory was applied and it was found that the captains improved on their use of leadership practices. This result is in line with the results of the current research in terms of showing the development of leadership qualities of individuals who attend leadership implementations.

In this study, students were given the opportunity to experience leadership through peer coaching. Students expressed that they felt more self-confident as their ideas were received and they were listened by their peers as a result of the activities they were leading. Furkan and Oznur stated that they were afraid to lead to or make mistakes at the beginning of the activity but as there was a progress in the study, they realized that these timid attitudes changed, and they became able to lead and their self-esteem increased. Furthermore, students also developed communication skills by exchanging ideas with their colleagues in this study. Schilling and Martinek (2001) have found in their study that young leaders have succeeded in developing skills such as teaching, communication, and anger management. Young leaders have also reported that they felt more confident during teaching and they have learned a lot about teaching methods. This study shows parallelism with the research results.

In the present study, the students stated that they gained behaviors such as taking responsibility, cooperation, making an effort, setting goals, making plans, solving problems, showing respect by leading their peers. Hellison (1995) has stated that helping others and leadership develop a person's responsibility because it includes having responsibility for others and thinking of others. Students are given the opportunity to lead groups that consist of two or three peers, and leaders are asked to provide feedback such as helping others, controlling misbehavior, and directing. Furthermore, they are required to make plans for the courses that they will be leading and to be prepared for the lessons. In dissertation thesis study of Melendez (2011), it has been stated that the young leaders have learned about helping and leading values using the experiential approach in the Effort Project. In terms of helping others, majority of participants have stated that they have gained the stage of helping while they have been working with children on helping others and doing the activities. Leadership which is one of the TPSR values have been learned by the participants because the Effort Project provided an opportunity for them to be in front of the children and participate in the activities with an experiential approach. Dewey (1938) describes the experimental approach as "learning by doing". Dewey also notes that learning takes place when education is based on experience. Participants of this study have learned the TPSR value of self-direction and the TPSR values of respect and caring. These results support the results of the current research.

According to the field notes obtained at the group meetings and reflection time discussions, it was seen that, the students understood the leadership, at the beginning of the study, as helping their peers and their teachers. At the time of reflection towards the end of the TPSR leadership program, the students found more features for the definition of leadership. In the first lessons, students expressed that a leader was a concerned, respectful, honest, just, knowledgeable and generally responsible individual. Towards the end of the study, the students developed their views on leadership and made a more comprehensive definition that adds features such as truth-telling, following his/her path, empathizing, reassuring and being polite. Similar to the participants in the present study, participants in the study of Walsh, Ozaeta, and Wright (2010) and Dunn (2012) have described leadership as not being the one who follows others, helps others in the classroom, and does what is right. Other studies (Gordon, 2010; Hammond-Diedrich \& Walsh, 2006; Walsh, 2007; Martinek, Schilling, \& Hellison, 2006) have shown that participants consider leadership with features not included in this study such as compassion, maturity, problem-solving skills, and patience. In the present study, students have had the experience to help them understand the behaviors of taking responsibility and to be the lead. The researcher has helped students to understand and implement the behaviors of responsibility and has actively involved in developing these behaviors. 
Vygotsky's approach to learning supports the direction and reinforcement of positive behaviors provided by teachers in terms of learning any kind of skill (Bodrova \& Leong, 2007). In the present study, students have often given leadership roles related to the activities in various courses in order to encourage them to learn the concept of leadership. For example, some students stated in the first lessons that they did not want to help their friends in some games and did not trust themselves in doing this, but in next lessons they helped and led them by teaching the movements. This finding related to the students show similarities with the findings of one of the participants in the study of Martinek, Schilling, and Hellison (2006) who has improved his leadership qualities, but instead of leading a group, he sometimes played basketball on his own, as in previous times. Some students have stated that they have had difficulties in terms of finding dance figures, shyness and not being able to make people listen to them and they have found solutions to these problems they have experienced such as making repetition, speaking, helping and offering ideas.

As a result of this study, the students expressed that their skills of showing respect, and taking responsibility, and cooperation and leadership skills developed. In the present study, at first, the researcher led the study and allowed the students to observe behaviors such as helping others and, giving feedback. Moreover, implementation was conducted within the activities to raise awareness about behaviors such as greeting, being polite, being respectful, managing anger, and not swearing. At the end of the study, most of the students stated that they started to use greetings more often in the classroom, home and in the circle of friends, they were nor more kind to their teachers and friends and they listened to their teachers more. The goal of the TPSR is to ensure participants exercise the concepts (Hellison, 2011). These statements show that the TPSR leadership training is effective in ensuring awareness and development in the expected behaviors of students.

As a result, most of the students stated that, they developed awareness of leadership concepts and helping others at the end of the TPSR leadership program, unveiled the skills of leading, learnt to ask for help without someone offering them to help, developed and strengthened their leadership skills. In the present study, it has been observed that Furkan had a will to lead without the demand of the researcher. Vygotsky (1980) stated that "Children's learning begins much earlier than school. There is always a past experience behind any learning that the child encounters at school". These students have been thought to have formed a level of confidence before participating in the program and without the support of the researcher. The researcher gave these students more opportunities to lead. On the other hand, Firat was very timid in the beginning of the study, but towards the end he gained self-confidence and gave information to the group and researchers about what he liked or disliked honestly and willingly and he tried to fulfill the given leadership tasks. During learning, children build new knowledge on their past experiences, and reflect and integrate it into their experiences (Creswell \& Clark, 2007; Lincoln \& Guba, 1985). Accordingly, in the assignment given to Dilan and Oznur for volleyball practice, these students prepared a volleyball lesson program with the support of the coach and the teacher, explained the purpose of the course, showed the activities, and showed the correct way of doing the movements to the students who made mistakes. The findings of the study conducted by Lee and Martinek (2009) related to the fact that students are improving in terms of values of helping and respecting each other support the findings of the present study. On the other hand, the study of Martinek, Schilling, and Johnson (2001) has not supported the results of the present study, as findings of them have shown that students have not demonstrated promising results especially on the aspects of self-direction and the helping others.

In the current study, the TPSR leadership program was implemented and it was aimed to give students leadership behaviors in particular. The students were experienced peer coaching through cooperative activities; opportunities for helping others, empathizing, finding solutions, respecting, leading, etc. have been provided. As a result of the study, it was observed that the students gained awareness of the leadership characteristics and their leadership behaviors increased. As a result, a 16-lessons TPSR leadership program was effective in terms of developing the leadership behaviors of the students in Sports High School.

\section{Recommendations}

- The reasons for observing an improvement in the behaviors of taking responsibility and leading in the experiment group but no change in the control group as a result of TPSR leadership program can be investigated.

- The implementation period may be conducted in the range of 1-5 years in order to follow-up with the leadership and TPSR life skills of the students. At the end of this process, participants who are qualified to become leaders can be directed to appropriate areas.

- While implementing the TPSR leadership program, cooperation between parents and teachers can be established to reinforce the TPSR values in the family and school environment.

- The TPSR leadership program can be implemented in sports clubs in cooperation with coaches to observe the leadership and responsibility behaviors of the athletes.

- The effectiveness of the TPSR leadership program in different age groups can be investigated. 


\section{References}

Atar, E., \& Oguz, O. (2009). Beden egitimi ve spor yuksekokulu ogrencilerinin liderlik davranislari [Leadership behaviors of physical education and sports college students]. Journal of Physical Education and Sport, 7(2), 51-59.

Bodrova, E., \& Leong, D. J. (2007). Play and early literacy: A Vygotskian approach. In K. A. Roskos, J. F. Christie, K. A. Roskos, \& J. F. Christie (Eds.), Play and literacy in early childhood: Research from multiple perspectives (2nd ed., pp. 185-200). Mahwah, NJ: Erlbaum.

Bulca, Y. (December, 2013). The effects of TPSR model on middle school students' self-efficacy and responsibility. Paper session presented at the meeting of 55th ICHPER. SD Anniversary World Congress 6 Exposition, Istanbul, Turkey.

Catalano, R. F., Berglund, M. L., Ryan, J. A., Lonczak, H. S., \& Hawkins, J. D. (2004). Positive youth development in the United States: Research findings on evaluations of positive youth development programs. Ann Am Acad Polit Soc Sci, 591(1), 98-124.

Collingwood, T.R. (1997). Helping At-Risk Youth through Physical Fitness Programming. Champaign, IL: Human Kinetics.

Creswell, J. W., \& Clark, L. V. (2007). Designing and Conducting Mixed Methods Research. Thousand Oaks, CA: Sage.

Cutforth, N. (2000). Connecting school physical education to the community through service-learning. Journal of Physical Education, Recreation, and Dance, 71(2), 39-45. doi:10.1080/07303084.2000.10606002

Cutforth, N., \& Puckett, K. M. (1999). An investigation into the organization, challenges and impact of an urban apprentice teacher program. The Urban Review, 31(2), 153-172. doi:10.1023/A:102323152

Danish, S. J., Forneris, T., \& Wallace, I. (2005). Sport-based life skills programming in the schools. Journal of Applied School Psychology, 21(2), 41-62.

Dewey, J. (1938). Experience and Education. New York, NY: Kappa Delta Pi.

Dunn, R. (2012). Every Flavor Beans: Children Constructing Meaning in a Responsibility-Based Program. (Electronic Thesis or Dissertation). Retrieved from https://etd.ohiolink.edu/

Escartí, A., Gutiérrez, M., Pascual, C., \& Llopis, R. (2010). Implementation of the personal and social responsibility model to improve self-efficacy during physical education classes for primary school children. International Journal of Psychology and Psychological Therapy, 10(3), 387-402.

Filiz, B. \& Demirhan, G. (2018). Development and examination of personal and social responsibility behaviors scale. Journal of Measurement and Evaluation in Education and Psychology, 9(1), 1-16.

Garbarino, J. (1997). Educating children in a socially toxic environment. Educational Leadership, 54(7), 12-16.

Gordon, B. (2010). An examination of the responsibility model in a New Zealand secondary school physical education program. Journal of Teaching in Physical Education, 29(1), 21-37. doi:10.1123/jtpe.29.1.21

Gould, D., \& Carson, S. (2008). Life skills development through sport: Current status and future directions. International Review of Sport and Exercise Psychology, 1(1), 58-78. doi:10.1080/17509840701834573

Grandzol, C. J. (2011). An exploratory study of the role of task dependence on team captains' leadership development. Journal of Leadership Education, 10(2), 57-70.

Halpin, W. \& Winer, B. J. (1957). A factorial study of the leader behavior description. In R. M. \& Stogdilland A. E. Coons (Eds.). Leader behavior description and measurement (pp. 39-51). Colombus, OH: Bureau of Business Research The Ohio State University.

Hammond-Diedrich, K. C., \& Walsh, D. (2006). Empowering youth through a responsibility-based cross-age teacher program: An investigation into impact and possibilities. Physical Educator, 63(3), 134-142.

Hellison, D. R. (1978). Beyond Balls and Bats: Alienated (and other) Youth in the Gym. Washington, DC: AAHPER.

Hellison, D. R. (1995). Teaching Responsibility through Physical Activity. Champaign, IL: Human Kinetics.

Hellison, D. R. (2011). Teaching Personal and Social Responsibility through Physical Activity (3th ed.). Champaign, IL: Human Kinetics.

Hellison, D. R. (2014). Fiziksel Aktivite Yoluyla Bireysel ve Sosyal Sorumluluk Ogretimi [Teaching Personal and Social Responsibility through Physical Activity] (Trans. ed. Filiz, B.) Ankara: Nobel.

Hellison, D., Cutforth, N., Kallusky, J., Martinek, T., Parker. M., \& Stiehl, J. (2000). Youth Development and Physical Activity. Champaign, IL: Human Kinetics.

Hellison, D., \& Walsh, D. (2002). Responsibility-based youth programs evaluation: Investigating the investigations. Quest, 54, 292-307. 
Holloway, I., \& Wheeler, S. (2010). Qualitative Research in Nursing and Healthcare. Chichester: Wiley-Blackwell.

Holt, N. L., \& Jones, M. I. (2008). Future directions for positive youth development and sport. In N.L. Holt (Ed.), Positive youth development in sport (pp. 122-132). London: Routledge.

Holt, N. L., \& Neely, K. C. (2011). Positive youth development through sport: A review. Revista Iberoamericana de Psicología Del Ejercicio Y El Deporte, 6(2), 299-316.

Kann, L., Kinchen, S. A., Williams, B. I., Ross, J. G., Lowry, R., Hill, C. V., ...Kolbe, L. J. (1998). Youth risk behavior surveillance-United States, 1997. MMWR CDC Surveill Summ, 47(3), 1-89.

Kinnear, R., \& Grey, C. (1999). SPSS for Windows Made Simple. New York, NY: Psychology Press, Hove.

Lee, O., \& Martinek, T. (2009). Navigating two cultures: An investigation of cultures of a responsibility-based physical activity program and school. Research Quarterly for Exercise and Sport, 80(2), 230-240. doi:10.1080/02701367.2009.10599557

Lincoln, Y. S., \& Guba, E. A. (1985). Naturalistic Inquiry. Beverly Hills, CA: Sage.

Martinek, T., \& Hellison, D. (2009). Youth Leadership in Sport and Physical Education. New York: Palgrave Macmillan.

Martinek, T., McLaughlin, D., \& Schilling, T. (1999). Project effort: Teaching responsibility beyond the gym. Journal of Physical Education, Recreation, and Dance, 70(6), 59-65.

Martinek, T., Schilling, T., \& Hellison, D. (2006). The development of compassionate and caring leadership among adolescents. Journal of Physical Education and Sport Pedagogy, 11(2), 141-157. doi:10.1080/17408980600708346

Martinek, T., Schilling, T., \& Johnson, D. (2001). Transferring personal and social responsibility of underserved youth to the classroom. The Urban Review, 33(1), 29-45. doi:10.1023/A:1010332812171

Melendez, A. (2011). Descriptive Study of TPSR Values and Life Skills Acquired in Project Effort and through other Sources and How They Have Guided Former Participants' Lives (The Degree Doctor of Philosophy). The North Carolina University.

Petitpas, A. J., Cornelius, A. E., Van Raalte, J. L., \& Jones, T. (2005.) A framework for planning youth sport programs that foster psychosocial development. The sport psychologist, 19(1), 63-80.

Sandford, R. A., Armour, K. M., \& Warmington, P. C. (2006). Re-engaging disaffected youth through physical activity programmes. British Educational Research Journal, 32(2), 251-271.

Schilling, T., \& Martinek, T. (2001). Learning through project effort. CYD Journal, 1(3), 24-30.

Silverman, D. (2006). Interpreting Qualitative Data (3rd Ed.), London: Sage.

Tabachnick, B., \& Fidell, L. (2013). Using Multivariate Statistics, 6th International Edition (Cover) Edn. New Jersey: Sage Publications, Thousand Oaks.

Vygotsky, L. S. (1980). Mind in society: The Development of Higher Psychological Processes. Cambridge, MA: Harvard university press.

Walsh, D. S. (2007). Supporting youth development outcomes: An evaluation of a responsibility model-based program. Physical Educator, 64(1), 48-56.

Walsh, D. S., Ozaeta, J., \& Wright, P. M. (2010). Transference of responsibility model goals to the school environment: Exploring the impact of a coaching club program. Physical Education and Sport Pedagogy, 15(1), 15-28. doi:10.1080/17408980802401252

Whitley, M. A., Hayden, L. A., \& Gould, D. (2016). Growing up in the Kayamandi Township: II. Sport as a setting for the development and transfer of desirable competencies. International Journal of Sport and Exercise Psychology, 14(4), 305-322. doi:10.1080/1612197X.2015.1036095

Wright, P. M., \& Burton, S. (2008). Implementation and outcomes of a responsibility-based physical activity program integrated nto an intact high school physical education class. Journal of Teaching Physical Education, 27(2), 138154.

Yildirim, A., \& Simsek, H. (2006). Sosyal Bilimlerde Nitel Arastirma Yontemleri [Qualitative Research Methods in the Social Sciences]. Ankara, Turkey: Seckin. 